\title{
Enhanced candicidal compound production by a new soil isolate Penicillium verruculosum MKH7 under submerged fermentation
}

\author{
Shruti Talukdar', Madhumita Talukdar', Manorama Buragohain ${ }^{1}$, Archana Yadav', R. N. S. Yadav² and T. C. Bora ${ }^{\text {** }}$
}

\begin{abstract}
Background: Microorganisms are a rich source of structurally diverse secondary metabolites that exert a major impact on the control of infectious diseases and other medical conditions. The biosynthesis of these metabolites can be improved by manipulating the nutritional or environmental factors. This work evaluates the effects of fermentation parameters on the production of a lactone compound effective against Candida albicans by Penicillium verruculosum MKH7 under submerged fermentation. Design-Expert version8.0 software was used for construction of the experimental design and statistical analysis of the experimental data.
\end{abstract}

Results: The important factors influencing antibiotic production selected in accordance with the Plackett-Burman design were found to be initial $\mathrm{pH}$, temperature, peptone, $\mathrm{MgSO}_{4} \cdot 7 \mathrm{H}_{2} \mathrm{O}$. Orthogonal central composite design and response surface methodology were adopted to further investigate the mutual interaction between the variables and identify the optimum values that catalyse maximum metabolite production. The determination coefficient $\left(R^{2}\right)$ of the fitted second order model was 0.9852 . The validation experiments using optimized conditions of initial pH 7 . 4, temperature $27{ }^{\circ} \mathrm{C}$, peptone $9.2 \mathrm{~g} / \mathrm{l}$ and $\mathrm{MgSO}_{4} .7 \mathrm{H}_{2} \mathrm{O} 0.39 \mathrm{~g} / \mathrm{l}$ resulted in a significant increase (almost 7 fold from 30 to $205.5 \mathrm{mg} / \mathrm{l})$ in the metabolite production which was in agreement with the prediction $(211.24 \mathrm{mg} / \mathrm{l})$. Stability of the compound was also assessed on the basis of its response to physical and chemical stresses.

Conclusions: So far as our knowledge goes, till date there are no reports available on the production of antibiotics by Penicillium verruculosum through media optimization using RSM. Optimization not only led to a 7 fold increase in metabolite yield but the same was achieved at much lesser time (8-10 days compared to the earlier 12-15 days). The enhanced yield of the antibiotic strongly suggests that the fungus $P$. verruculosum MKH7 can be efficiently used for antibiotic production on a large scale.

\section{Background}

Fungal infections have increased dramatically over the last few decades and this rise in the number of opportunistic fungal infections has stimulated research towards the development of novel antifungal agents [1]. Currently the fourth most common cause of nosocomial infection is the Candida species [2]. Notorious among all the Candida species is the Candida albicans [3].

\footnotetext{
* Correspondence: taruncbora@gmail.com

${ }^{1}$ Biotechnology Division, CSIR-North-East Institute of Science \& Technology, Jorhat 785006, Assam, India

Full list of author information is available at the end of the article
}

Microbes are one of the most productive sources of natural products from which antibiotics are derived [4]. Fungi, particularly the filamentous ones, are highly potential reservoirs of products with excellent antagonistic activity against human pathogens [5]. A variety of secondary metabolites including antimicrobial substances is reported to have been produced by the fermentation of Penicillium species [6-8]. Their production depends upon the nutrition and cultivation conditions of the strains [9]. The nutritional requirements and physical parameters can be managed and controlled to increase the productivity of microbial metabolites [10]. However, these processes are usually quite long and arduous when 
accomplished using routine techniques such as a onefactor-at-a-time method [11].

In any optimization process, first the screening of the important variables has to be done and subsequently estimation of optimal levels of these factors [12]. Statistical methods are quite advantageous with reference to a rapid identification of the significant factors and also decrease in the total number of experiments [13-16]. Application of statistical methods like Plackett-Burman design (PBD) and response surface methodology (RSM) in process optimization have been reported [17, 18]. The shortcomings of conventional methods have been eliminated by RSM [19-21]. RSM is a fast and effective tool as it reduces the number of experimental trials and also helps to compare the significance of a number of variables at a time.

The objective of the present study was to identify the best conditions for the production of a candicidal compound by Penicillium verruculosum MKH7 (active against Candida albicans) by statistical approach. Plackett-Burman design (PBD) was used to screen the most significant parameters affecting metabolite production followed by a central composite design (CCD) of response surface methodology (RSM) to identify the optimum levels of the significant factors for maximizing the metabolite production.

\section{Results}

The promising fungal strain was identified as Penicillium verruculosum MKH7 [GenBank: HM049911] on the basis of ITS region sequencing and phylogenetic analysis (Fig. 1). In order to find out the most suitable carbon and nitrogen sources, the one-factor-at-a-time (OFAT) method was employed and on the basis of this, dextrose and peptone respectively were found to be the most favourable for the production of the bioactive metabolite. The composition of the production medium was selected on the basis of preliminary experiments (single factor optimization study, other factors kept constant).

\section{Characterization of the antifungal metabolite}

The UV spectral data exhibited strong absorption $(\lambda$-max) at 200 and $210 \mathrm{~nm}$ indicating the presence of lactone ring. The IR spectral absorption at $1721 \mathrm{~cm}^{-1}$ and $1751 \mathrm{~cm}^{-1}$ revealed the presence of carbonyl group. Other bands that appeared are 3435, 2925, $2850\left(\mathrm{OH}\right.$ group $-\mathrm{CH}_{2}-$ ), $1638 \mathrm{~cm}^{-1}$ (non-conjugated double bond). In the NMR spectrum the signals are $\delta 1.76(\mathrm{~s}), \delta 2.64, \delta 3.90, \delta 4.81$, 85.05, $\delta 5.13, \delta 5.20$ and $\delta 5.48$. The ${ }^{13} \mathrm{C}$ NMR peaks at $176.19,176.51$ and 165.24 strongly favors the presence of carbonyl groups. Other prominent peaks are 64.69, 94.15 and 94.33 indicating the presence of a lactone ring. The alkene carbons are also found to be present at 110.93, 121.61 and 144.90. The remaining methyl and methylene carbons are found to be present at $21.03\left(\mathrm{CH}_{3}\right), 22.40$, 23.14, 38.36, $45.25\left(\mathrm{CH}_{2}\right.$ peaks). The $\mathrm{C}, \mathrm{H}, \mathrm{N}$ analysis gave the estimation of carbon (56.45\%), hydrogen (7.91\%) and nitrogen was negligible $(0.78 \%)$. Based on the above data, the structure was deduced as 4, 5- dihydroxy-3- (7-oxooct-2-enyl)-dihydro-furan-2-one (Fig. 2).

\section{Optimization by Plackett-Burman design}

The significance of the seven factors viz. dextrose, peptone, $\mathrm{NaCl}$, initial $\mathrm{pH}$, temperature, fermentation time, $\mathrm{MgSO}_{4} \cdot 7 \mathrm{H}_{2} \mathrm{O}$ for metabolite production was examined by Plackett-Burman design. The levels of the factors in the design are given in Table 1 . Table 2 shows the experimental design with the seven factors under investigation as well as the effect of each factor on the response and significant levels. Twelve runs were carried out to screen the effect of the variables (including 5 dummy variables) on metabolite production. A first-order model was fitted to the results obtained from the 12 experiments:

Distance 0.02

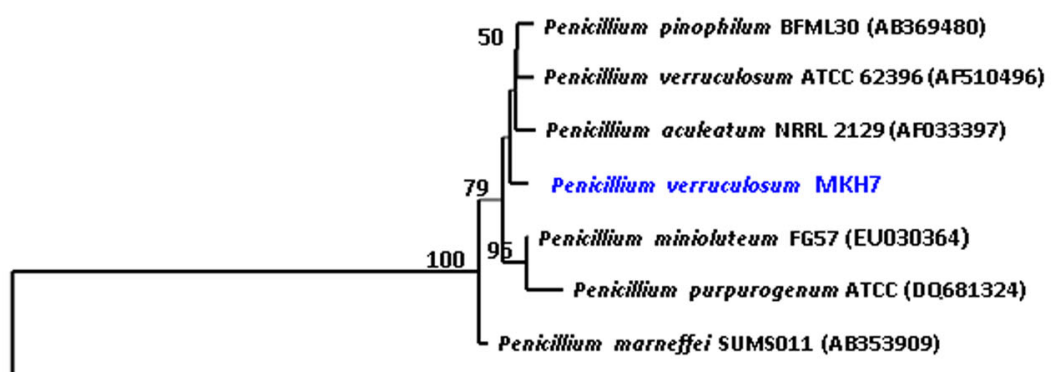

Fusarium oxpsponum f. sp. lycopersici ATCC 34298 (00452454)

Fig. 1 Phylogenetic tree showing relationship Penicillium verruculosum MKH7 and related taxa, based on analysis of ITS region. The numbers on the nodes indicate how often (no. of times, \%) the species to the right are grouped together in 100 bootstrap samples. Fusarium oxysporum $\mathrm{f}$. sp. lycopersici ATCC 34298 was used as an outgroup. Bar, 0.05 substitution per site 


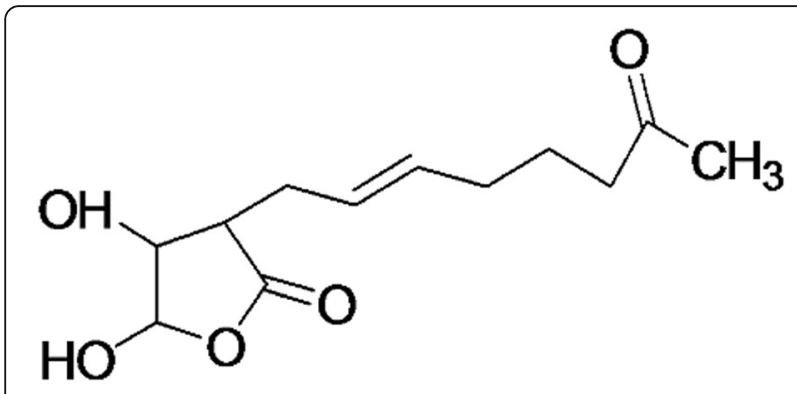

Fig. 2 Predicted structure of the antifungal metabolite

$$
\begin{aligned}
\mathrm{Y}(\mathrm{mg} / \mathrm{l})= & 9.13-2.79 \mathrm{~A}+3.23 \mathrm{~B} \\
& +3.76 \mathrm{C}-3.23 \mathrm{D}+2.76 \mathrm{E} \\
& +1.19 \mathrm{~F}+3.69 \mathrm{G}
\end{aligned}
$$

The $t$-test and $P$-values were used to identify the effect of each factor on metabolite production. A P-value of less than 0.05 indicates that the model terms are significant. Table 3 shows that peptone, initial $\mathrm{pH}$, temperature and $\mathrm{MgSO}_{4} .7 \mathrm{H}_{2} \mathrm{O}$ are the most significant factors $(P<0.05)$. These were then selected for further optimization to obtain a maximum response. The fitness of the model was determined by the coefficient of determination $R^{2}$, which in this case was 0.9238 .

\section{Response surface analysis}

Based on the Plackett-Burman design, response surface methodology (RSM) using CCD was employed to determine the optimal levels of the four most significant factors (initial $\mathrm{pH}$, temperature, peptone and $\mathrm{MgSO}_{4} \cdot 7 \mathrm{H}_{2} \mathrm{O}$ ) for enhancing metabolite production. The four independent variables were studied at five different levels $(-2,-1,0,+1$, +2 ) and a set of 30 experiments with different combination of the selected variables were carried out. The lowest and the highest values of the variables were: initial $\mathrm{pH}, 7$ and 8; temperature, 25 and $30{ }^{\circ} \mathrm{C}$; peptone, 7.5 and $10 \mathrm{~g} / \mathrm{l}$; $\mathrm{MgSO}_{4} .7 \mathrm{H}_{2} \mathrm{O}, 0.3$ and $0.5 \mathrm{~g} / \mathrm{l}$. The actual yield of the bioactive metabolite and the yield predicted by the model equation are given in Table 4. Regression analysis was

\begin{tabular}{|c|c|c|c|}
\hline \multirow[t]{2}{*}{ Factor } & \multicolumn{3}{|c|}{ Code level } \\
\hline & -1 & 0 & +1 \\
\hline A-Dextrose (g/l) & 20 & 25 & 30 \\
\hline B-Peptone (g/l) & 5 & 7.5 & 10 \\
\hline C-Initial pH & 5 & 7 & 9 \\
\hline D-Temperature $\left({ }^{\circ} \mathrm{C}\right)$ & 25 & 30 & 35 \\
\hline E-NaCl (g/l) & 1 & 3 & 5 \\
\hline F-Fermentation time (days) & 10 & 12.5 & 15 \\
\hline $\mathrm{G}-\mathrm{MgSO}_{4} \cdot 7 \mathrm{H}_{2} \mathrm{O}(\mathrm{g} / \mathrm{l})$ & 0.1 & 0.3 & 0.5 \\
\hline
\end{tabular}
performed to fit the response function (metabolite

Table 1 Levels of the factors tested in the Plackett-Burman design
Table 2 Plackett-Burman design matrix for evaluating significant factors affecting candicidal metabolite production by Penicillium verruculosum

\begin{tabular}{ccccccccccccc}
\hline Run & $\mathrm{A}$ & $\mathrm{B}$ & $\mathrm{C}$ & $\mathrm{D}$ & $\mathrm{E}$ & $\mathrm{F}$ & $\mathrm{G}$ & $\mathrm{H}$ & $\mathrm{I}$ & $\mathrm{J}$ & $\mathrm{K}$ & Yield $(\mathrm{mg} / \mathrm{l})$ \\
\hline 1 & 1 & 1 & -1 & 1 & 1 & 1 & -1 & -1 & -1 & 1 & -1 & 3.1 \\
2 & 1 & -1 & -1 & -1 & 1 & -1 & 1 & 1 & -1 & 1 & 1 & 3.3 \\
3 & -1 & -1 & -1 & 1 & -1 & 1 & 1 & -1 & 1 & 1 & 1 & 3.2 \\
4 & 1 & -1 & 1 & 1 & 1 & -1 & -1 & -1 & 1 & -1 & 1 & 3.7 \\
5 & -1 & 1 & 1 & -1 & 1 & 1 & 1 & -1 & -1 & -1 & 1 & 30.5 \\
6 & -1 & 1 & 1 & 1 & -1 & -1 & -1 & 1 & -1 & 1 & 1 & 3.5 \\
7 & 1 & -1 & 1 & 1 & -1 & 1 & 1 & 1 & -1 & -1 & -1 & 6.4 \\
8 & -1 & 1 & -1 & 1 & 1 & -1 & 1 & 1 & 1 & -1 & -1 & 15.5 \\
9 & 1 & 1 & 1 & -1 & -1 & -1 & 1 & -1 & 1 & 1 & -1 & 18.0 \\
10 & -1 & -1 & 1 & -1 & 1 & 1 & -1 & 1 & 1 & 1 & -1 & 15.2 \\
11 & -1 & -1 & -1 & -1 & -1 & -1 & -1 & -1 & -1 & -1 & -1 & 3.6 \\
12 & 1 & 1 & -1 & -1 & -1 & 1 & -1 & 1 & 1 & -1 & 1 & 3.5 \\
\hline
\end{tabular}

${ }^{*} \mathrm{H}, \mathrm{I}, \mathrm{J}, \mathrm{K}$ - Dummy variables

production) with the experimental data. The second-order polynomial equation for metabolite production is

$$
\begin{aligned}
\mathrm{Y}(\mathrm{mg} / \mathrm{l})= & 211.23-2.25 \mathrm{~A}-4.3 \mathrm{~B} \\
& +2.4 \mathrm{C}-2.9 \mathrm{D}-2.41 \mathrm{AB}+1.05 \mathrm{AC} \\
& +0.79 \mathrm{AD}-2.17 \mathrm{BC}-5.2 \mathrm{BD}-5.44 \mathrm{CD} \\
& -34.2 \mathrm{~A}^{2}-37.99 \mathrm{~B}^{2}-36.5 \mathrm{C}^{2}-34.74 \mathrm{D}^{2}
\end{aligned}
$$

where $\mathrm{A}, \mathrm{B}, \mathrm{C}$ and $\mathrm{D}$ are the coded factors of initial $\mathrm{pH}$ and temperature, peptone and $\mathrm{MgSO}_{4} \cdot 7 \mathrm{H}_{2} \mathrm{O}$ respectively.

From the results of $F$-test analysis of variance (Table 5), it was found that the regression was statistically significant $(P<0.0001)$. The Model $F$-value of 71.36 implies the model is significant. Values of "Prob $>F$ " less than 0.05 indicate model terms are significant. In this case $\mathrm{CD}, \mathrm{A}^{2}, \mathrm{~B}^{2}, \mathrm{C}^{2}, \mathrm{D}^{2}$ are significant model terms. The fit of

\begin{tabular}{|c|c|c|c|c|c|}
\hline Source & SS & DF & MS & F-value & $P$-value Prob $>F$ \\
\hline Model & 784.52 & 7 & 112.07 & 6.93 & 0.0401 \\
\hline Dextrose & 93.52 & 1 & 93.52 & 5.78 & 0.0740 \\
\hline Peptone & 124.81 & 1 & 124.81 & 7.72 & 0.0499 \\
\hline Initial pH & 169.50 & 1 & 169.50 & 10.48 & 0.0317 \\
\hline Temperature & 124.81 & 1 & 124.81 & 7.72 & 0.0499 \\
\hline $\mathrm{NaCl}$ & 91.30 & 1 & 91.30 & 5.65 & 0.0763 \\
\hline Fermentation time & 17.04 & 1 & 17.04 & 1.05 & 0.3627 \\
\hline $\mathrm{MgSO}_{4} \cdot 7 \mathrm{H}_{2} \mathrm{O}$ & 163.54 & 1 & 163.54 & 10.11 & 0.0335 \\
\hline
\end{tabular}
the model was checked by the coefficient of determination $\mathrm{R}^{2}$ which was calculated to be 0.9852 . The $\mathrm{R}^{2}$ value is always between 0 and 1 , and a value $>0.75$ indicates aptness of the model. The "Pred R-Squared" of 0.9210 is in reasonable agreement with the "Adj R-

Table 3 ANOVA of the Plackett-Burman Design

*SS sum of squares, DF degrees of freedom, MS mean square 
Table 4 Central Composite Design in coded units

\begin{tabular}{|c|c|c|c|c|c|}
\hline Run & $\begin{array}{l}\text { Initial } \\
\mathrm{pH}(\mathrm{A})\end{array}$ & $\begin{array}{l}\text { Temperature } \\
\text { (B) }\end{array}$ & $\begin{array}{l}\text { Peptone } \\
\text { (C) }\end{array}$ & $\begin{array}{l}\mathrm{MgSO}_{4} \cdot 7 \mathrm{H}_{2} \mathrm{O} \\
\text { (D) }\end{array}$ & $\begin{array}{l}\text { Metabolite } \\
\text { yield (mg/l) }\end{array}$ \\
\hline 1 & 0 & 0 & 0 & 0 & 217.56 \\
\hline 2 & -1 & 1 & -1 & -1 & 70.34 \\
\hline 3 & 0 & 0 & 0 & 2 & 67.8 \\
\hline 4 & -1 & 1 & -1 & 1 & 73.78 \\
\hline 5 & 1 & -1 & 1 & -1 & 73.78 \\
\hline 6 & 1 & 1 & -1 & 1 & 55 \\
\hline 7 & 0 & 0 & 0 & 0 & 210.7 \\
\hline 8 & 1 & 1 & 1 & 1 & 32.15 \\
\hline 9 & 0 & -2 & 0 & 0 & 71.32 \\
\hline 10 & 0 & 0 & 0 & 0 & 210.65 \\
\hline 11 & 0 & 0 & 0 & 0 & 217.5 \\
\hline 12 & 1 & 1 & -1 & -1 & 66.2 \\
\hline 13 & -1 & -1 & 1 & -1 & 77.7 \\
\hline 14 & 0 & 0 & 2 & 0 & 80.25 \\
\hline 15 & 1 & -1 & 1 & 1 & 75.2 \\
\hline 16 & 0 & 0 & 0 & 0 & 205.5 \\
\hline 17 & 1 & 1 & 1 & -1 & 75 \\
\hline 18 & 1 & -1 & -1 & 1 & 80.14 \\
\hline 19 & -1 & 1 & 1 & 1 & 62 \\
\hline 20 & 2 & 0 & 0 & 0 & 80 \\
\hline 21 & -1 & -1 & 1 & 1 & 66.5 \\
\hline 22 & -1 & -1 & -1 & -1 & 78.5 \\
\hline 23 & 0 & 0 & 0 & 0 & 205.46 \\
\hline 24 & 0 & 0 & 0 & -2 & 77.58 \\
\hline 25 & 0 & 0 & -2 & 0 & 51.3 \\
\hline 26 & -1 & -1 & -1 & 1 & 70.85 \\
\hline 27 & 1 & -1 & -1 & -1 & 46.76 \\
\hline 28 & 0 & 2 & 0 & 0 & 48 \\
\hline 29 & -2 & 0 & 0 & 0 & 70 \\
\hline 30 & -1 & 1 & 1 & -1 & 78.45 \\
\hline
\end{tabular}

Squared" of 0.9714. The "Lack of Fit F-value" of $4.69 \mathrm{im}$ plies the Lack of Fit is not significant. As evident from the linear coefficient of 2.4, the effect of peptone was the highest on the yield of the metabolite while low $P$ values $(P<0.05)$ indicated that the interaction between peptone and $\mathrm{MgSO} 4.7 \mathrm{H} 2 \mathrm{O}$ was significant [22]. Statistical analysis helps to ascertain the factors generating signals that are large in comparison to noise [23]. Adequate precision measures the signal to noise ratio and a ratio greater than 4 is desirable. In this case, the ratio of 23.049 for antibiotic yield indicates an adequate signal. From the maximum point of the model, the optimal values of the four significant components were calculated to be $\mathrm{A}=-0.032, \mathrm{~B}=-0.054, \mathrm{C}=0.04$ and $\mathrm{D}=-0.0423$ (in coded units) which corresponds to the values of
Table 5 Regression results of the CCD

\begin{tabular}{lllll}
\hline $\begin{array}{l}\text { Factor } \\
\text { Intercept }\end{array}$ & Coefficient estimate & F-value & Prob $>F$ & Significance \\
Model & & & & \\
\hline A & -2.25 & 71.36 & $<0.0001$ & Significant \\
B & -4.3 & 1.20 & 0.2911 & \\
C & 2.4 & 4.39 & 0.0536 & \\
D & 2.9 & 1.34 & 0.2643 & \\
AB & -2.41 & 2.06 & 0.1718 & \\
AC & 1.05 & 0.92 & 0.3529 & \\
AD & 0.79 & 0.18 & 0.6811 & \\
BC & -2.17 & 0.098 & 0.7581 & \\
BD & -5.2 & 0.74 & 0.4024 \\
CD & -5.44 & 4.26 & 0.0567 \\
A $^{2}$ & -34.2 & 4.69 & 0.0469 \\
B $^{2}$ & -37.99 & 316.76 & $<0.0001$ & \\
$C^{2}$ & -36.5 & 391.87 & $<0.0001$ & \\
$D^{2}$ & -34.74 & 360.97 & $<0.0001$ \\
\hline
\end{tabular}

*Lack of Fit $=4.69$, Coefficient of Variation $(\%)=10.41, R^{2}=0.9852$,

Adj R-Squared $=0.9714$, Pred R-Squared $=0.9210$

7.4, $27{ }^{\circ} \mathrm{C}, 9.2 \mathrm{~g} / \mathrm{l}$ and $0.39 \mathrm{~g} / \mathrm{l}$ for initial $\mathrm{pH}$, temperature, peptone, $\mathrm{MgSO}_{4} \cdot 7 \mathrm{H}_{2} \mathrm{O}$ respectively. The model predicted a maximum response of $211.24 \mathrm{mg} / \mathrm{l}$ metabolite yield at this point which was significantly higher than that obtained using the original medium. The observed versus the predicted response is shown in Fig. 3. The predicted data from the model are in agreement with the observed one as is evident from the figure. Figure 4 shows the normal plot of residuals, the linear pattern indicating normality in the error term [24]. A plot of residuals versus the predicted response is shown in Fig. 5. As the residuals are scattered randomly so the variance of the original observation is constant for all the values of $Y$ [24]. The interaction between two variables by keeping the other two at zero level are depicted in the 3D response surface curves (Fig. 6).

\section{Validation of the optimized condition}

Validation of the statistical model and regression equation was performed by running the optimization program with Design Expert within the experiment range investigated. Validation experiment was performed in triplicate tests.

\section{Stability of the metabolite}

The response of the bioactive metabolite to physical and chemical stresses was examined. It was stable at low temperatures ranging from -80 to $60{ }^{\circ} \mathrm{C}$ for $6 \mathrm{~h}$. There was a moderate decrease in activity on heating the metabolite to $100{ }^{\circ} \mathrm{C}$. There was complete loss of activity upon exposure to temperatures beyond $100{ }^{\circ} \mathrm{C}$. Compound was susceptible to extreme values of $\mathrm{pH}$, being 


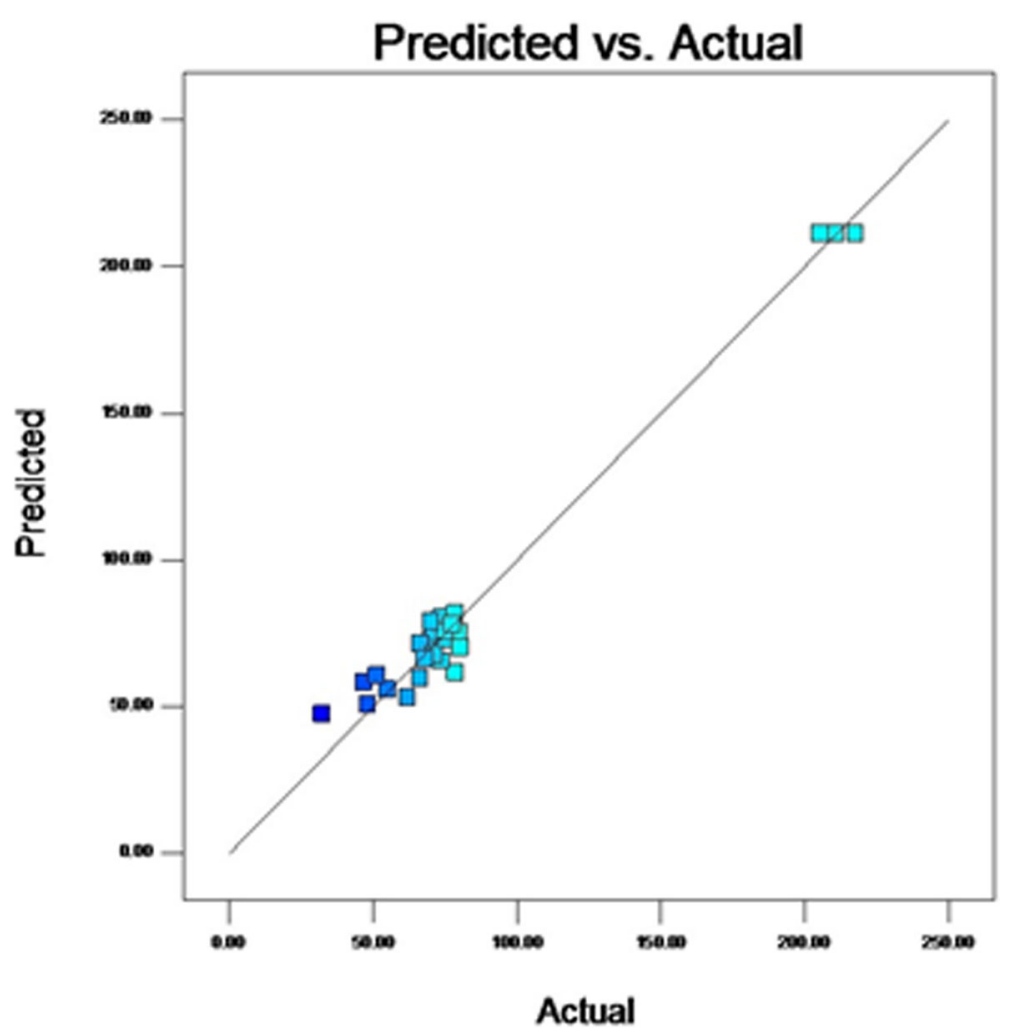

Fig. 3 Plot of the observed versus the predicted response

most stable in the range of 5-7. Results are presented in Fig. 7.

\section{Discussion}

Genus Penicillium is a potential producer of a vast array of secondary metabolites like tremorgenic toxins, pigments, potentiators of nerve growth factor, inducers of osteoblast differentiation and most importantly antibiotics including macrocyclic polylactones [25-30]. In this report, characterization of the candicidal compound revealed the presence of lactone ring and carbonyl groups as prominent components. Breinholt et al. [27] had also reported the isolation of antifungal macrocyclic polylactones from $P$. verruculosum. Production of secondary metabolites is influenced by a number of cultivation parameters ranging from precursors to trace elements [31]. The combined effects of all the involved factors cannot be determined through traditional practices like the classical one-factor-at-a-time approach [32]. Interactions among factors and multifactor optimization cannot be evaluated using this method. These limitations can be overcome by statistical tools like RSM that enable the study of the effects of several factors simultaneously and determine the optimum values of the variables so as to maximize the response [33, 34]. PBD was applied to determine the main factors affecting metabolite production. In this investigation, from the PBD analysis it was found that among the variables tested, four factors viz. initial $\mathrm{pH}$, temperature, peptone and $\mathrm{MgSO}_{4} \cdot 7 \mathrm{H}_{2} \mathrm{O}$, were found to have significant effect on the production of bioactive metabolite by the strain P.verruculosum MKH7. Medium pH, temperature [35] and peptone [36] have been reported to be some of the most important experimental parameters influencing bioactive secondary metabolite production by Penicillium species. Dextrose and peptone were found to be important also in the production of sclerotiorin from $P$. sclerotiorum [8]. However Brian et al. [30] reported that glucose was the best carbon source for wortmannin synthesis from $P$. wortmanni while glycerol was most favourable for mevastatin production by $P$. citrinum [37] The reason for this dissimilarity might be the use of different strains and different culturing conditions, yet another reason might be the selection of different carbon sources in the original medium [24]. Moreover, the sources for growth and secondary metabolism may be different. For example, glucose may be beneficial for growth but the same may not be true for secondary metabolite formation [38]. Peptone played a crucial role in the biosynthesis of the metabolite sclerotiorin by P. sclerotiorum [39]. Several factors influence the effect of nitrogen sources on synthesis of secondary metabolite. The sources that are important for growth may negatively affect secondary metabolic 


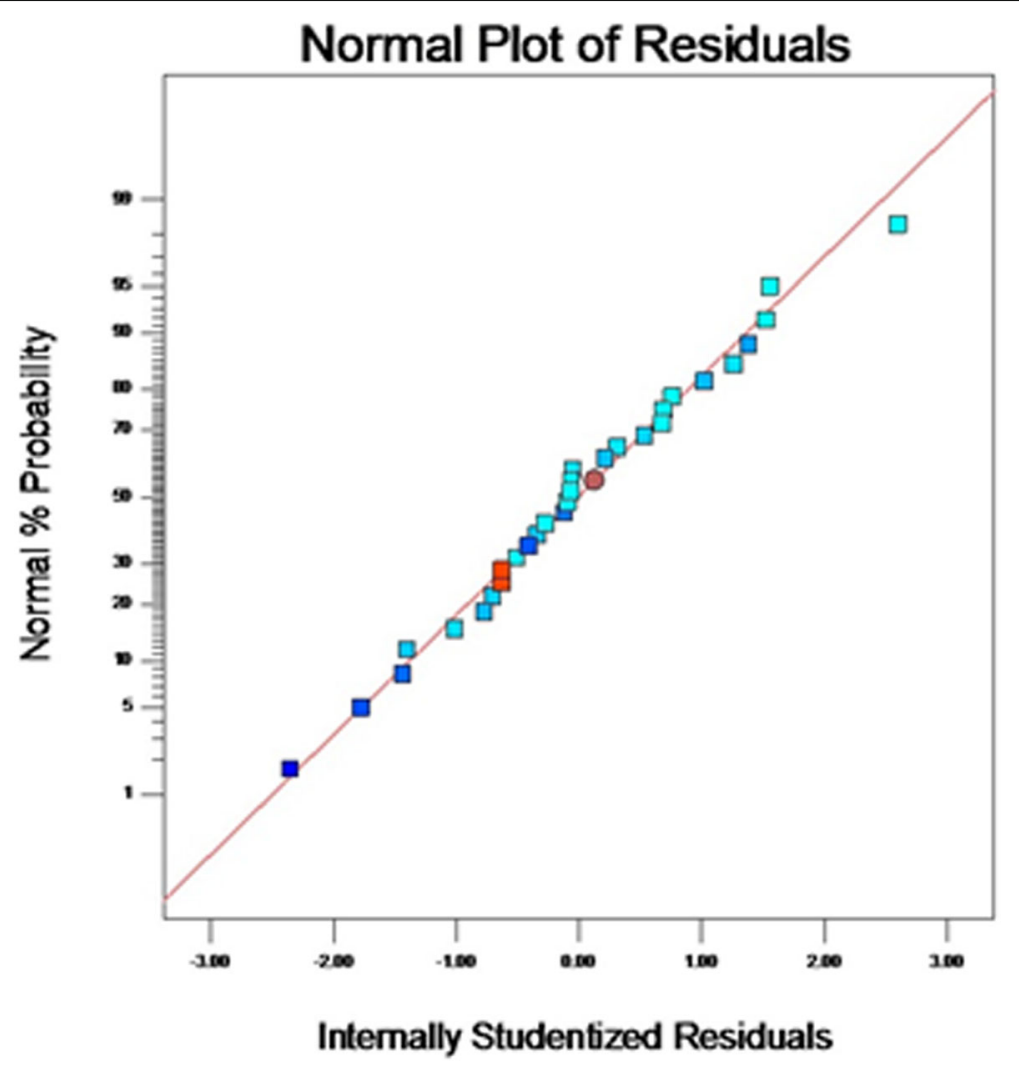

Fig. 4 Normal probability of internally studentized residuals

pathways; there are reports on the negative effects of ammonium salts [38].

Under the RSM optimized conditions of initial pH7.4, temperature $27{ }^{\circ} \mathrm{C}$, peptone $9.2 \mathrm{~g} / \mathrm{l}$ and $\mathrm{MgSO}_{4} .7 \mathrm{H}_{2} \mathrm{O}$ $0.39 \mathrm{~g} / \mathrm{l}$, a maximum metabolite production of $211.24 \mathrm{mg} / \mathrm{l}$ was predicted, simultaneously proved by triplicate experiments conducted under the same conditions. $\mathrm{MgSO}_{4} .7 \mathrm{H}_{2} \mathrm{O}$ was found to be essential also for the synthesis of mevastatin from $P$. citrinum [37]. Trace elements like $\mathrm{Zn}, \mathrm{Mn}, \mathrm{Fe}, \mathrm{Cu}$ are important for microbial growth because of their presence in metalloenzymes or as enzyme activators [24] while $\mathrm{Mg}$ and $\mathrm{Ca}$ are macronutrients in fungal nutrition [37]. Contrary to this, in our case the effect of $\mathrm{Mg}$ on metabolite yield was significant. Similar inference was also made on the production of sclerotiorin by $P$. sclerotiorum [8]. Temperature and $\mathrm{pH}$ affect the regulation of molecules like ATP which in turn influence the regulation of metabolic pathways, coupled reactions and functional yields at the membrane and cell wall level [39]. A change in the concentration of hydrogen ions may change the redox fluxes and oxidative state of energy molecules like ATP, thereby causing diverse metabolism and generating different products [40]. Brian, 1946 [41] reported that high initial $\mathrm{pH}(>6)$ of media was best for development of fungistatic activity by Penicillium terlikowskii. Similar observation was also made for the production of antimicrobial agent by $P$. viridicatum [42]. Metabolic activity of fungus may be terminated by low temperature while high temperature kills the fungal cell [43]. The optimal temperature range for the production of the antibiotic and nephrotoxin, citrinin, by $P$. viridicatum was $25-30{ }^{\circ} \mathrm{C}$ [44]. Previous studies have shown that a temperature of $25^{\circ} \mathrm{C}$ was found to be optimal in a number of cases [43].

The use of polyene antibiotics in clinical practice is restricted due to problems in their stability which is affected by extreme values of $\mathrm{pH}$ and temperature leading to total loss of drug potency. The stability of lactone antibiotics depends on the tetraene chromophore of the molecule and heating beyond $100{ }^{\circ} \mathrm{C}$ leads to cleavage of these four conjugated double bonds resulting in the degradation of the antibiotic [45]. According to Stark, 2000 [46], neutral aqueous suspensions of natamycin can remain stable at $50{ }^{\circ} \mathrm{C}$ for several days and a slight decrease in biological activity was observed after heating for $20 \mathrm{~min}$ at $110{ }^{\circ} \mathrm{C}$. The polyene antifungal agent nystatin is more active at low temperature $\left(30-25{ }^{\circ} \mathrm{C}\right)$ while amphotericinB is at $41{ }^{\circ} \mathrm{C}$ and their activity against C. albicans is stable at $\mathrm{pH}$ between 5 and 7 [47]. Similar observation was made by Raab, 1972 [45], on the stability of natamycin at different $\mathrm{pH}$. Likewise, phoslactomycin $\mathrm{B}$ is most stable at a $\mathrm{pH}$ of 6.63 [48]. High $\mathrm{pH}$ results in 


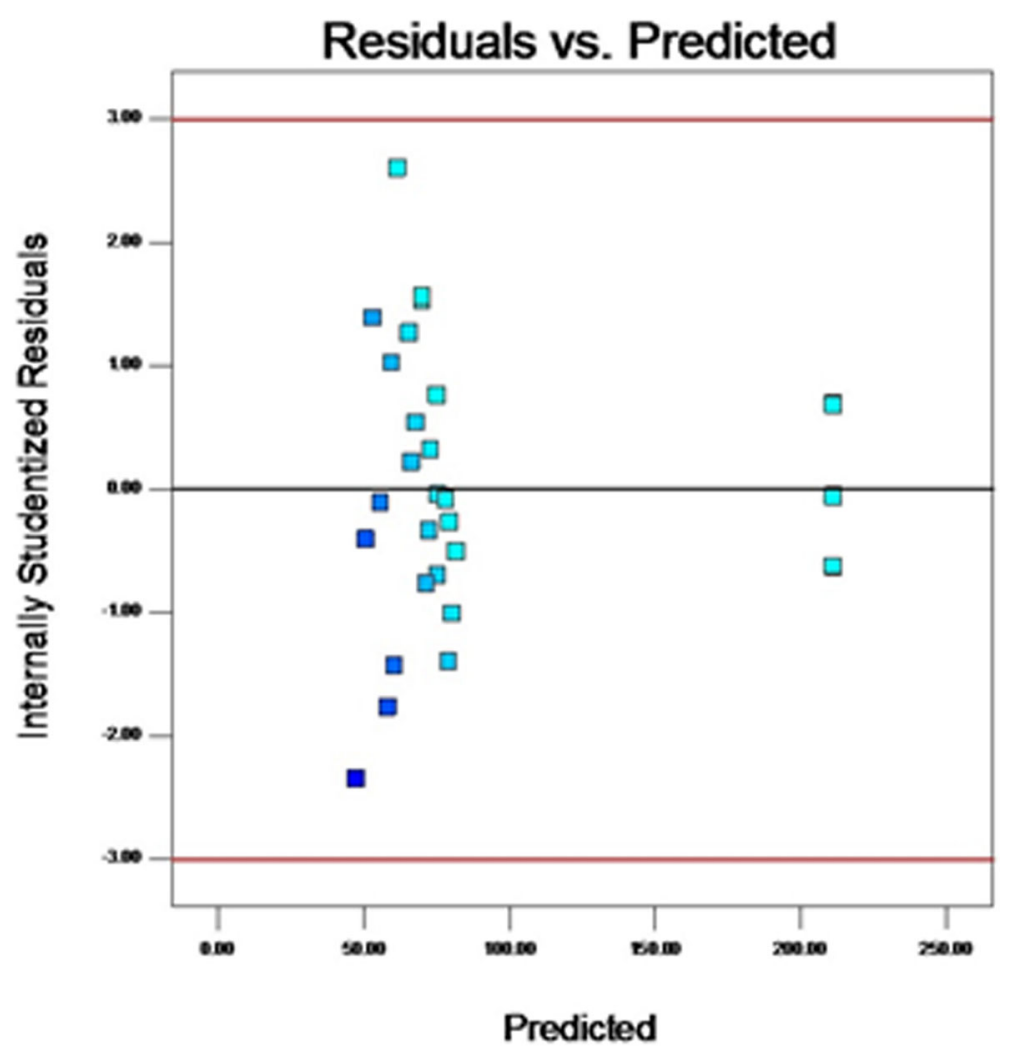

Fig. 5 Plot of internally studentized residuals vs. predicted response

saponification of the lactone and additional decomposition due to a series of retroaldol reactions while low $\mathrm{pH}$ might bring about the hydrolysis of the glycosidic bond [49].

So far as our knowledge goes, till date there are no reports available on the production of antibiotics by Penicillium verruculosum through media optimization using RSM. The enhanced yield of the antibiotic strongly suggests that the fungus $P$. verruculosum $\mathrm{MKH7}$ can be efficiently used for antibiotic production on a large scale. Optimization not only led to a 7 fold increase in metabolite yield but the same was achieved at much lesser time (8-10 days compared to the earlier $12-15$ days). In conclusion, statistical methods can be effectively utilized for arriving at optimal solutions and in analysing the interactive effects of the parameters thereby leading to improved metabolite production.

\section{Conclusion}

This is the first report on the production of antifungal compound by Penicillium verruculosum through media optimization using RSM. From the Plackett-Burman design analysis it was found that among the variables tested, four factors $v i z$. initial $\mathrm{pH}$, temperature, peptone and $\mathrm{MgSO}_{4} \cdot 7 \mathrm{H}_{2} \mathrm{O}$, were found to have significant effect on the production of bioactive metabolite by the strain
P.verruculosum MKH7. The RSM optimized conditions of initial pH7.4, temperature $27^{\circ} \mathrm{C}$, peptone $9.2 \mathrm{~g} / \mathrm{l}$ and $\mathrm{MgSO}_{4} .7 \mathrm{H}_{2} \mathrm{O} 0.39 \mathrm{~g} / \mathrm{l}$ predicted a maximum metabolite production of $211.24 \mathrm{mg} / \mathrm{l}$ which was proved by triplicate experiments conducted under the same conditions. A 7 fold increase in metabolite yield was obtained at a much lesser time. In conclusion, statistical methods can be effectively utilized for arriving at optimal solutions and in analysing the interactive effects of the parameters thereby leading to improved metabolite production.

\section{Methods}

\section{Producer organism}

Assay of antibiotic study by agar well diffusion method [50] was carried out to select the strain having the most promising candicidal activity. The test organism used was Candida albicans (MTCC 3017) obtained from Microbial Type Culture Collection (MTCC) and Gene Bank, Institute of Microbial Technology (IMTECH), Chandigarh, India. Based on this study, the strain MKH7 isolated from soil collected from North-East India, one of the Megabiodiversity Hot spots, was selected for a detailed analysis to optimise the culture parameters. Disc diffusion method [51] was followed to confirm the efficacy of the compound isolated from MKH7. 

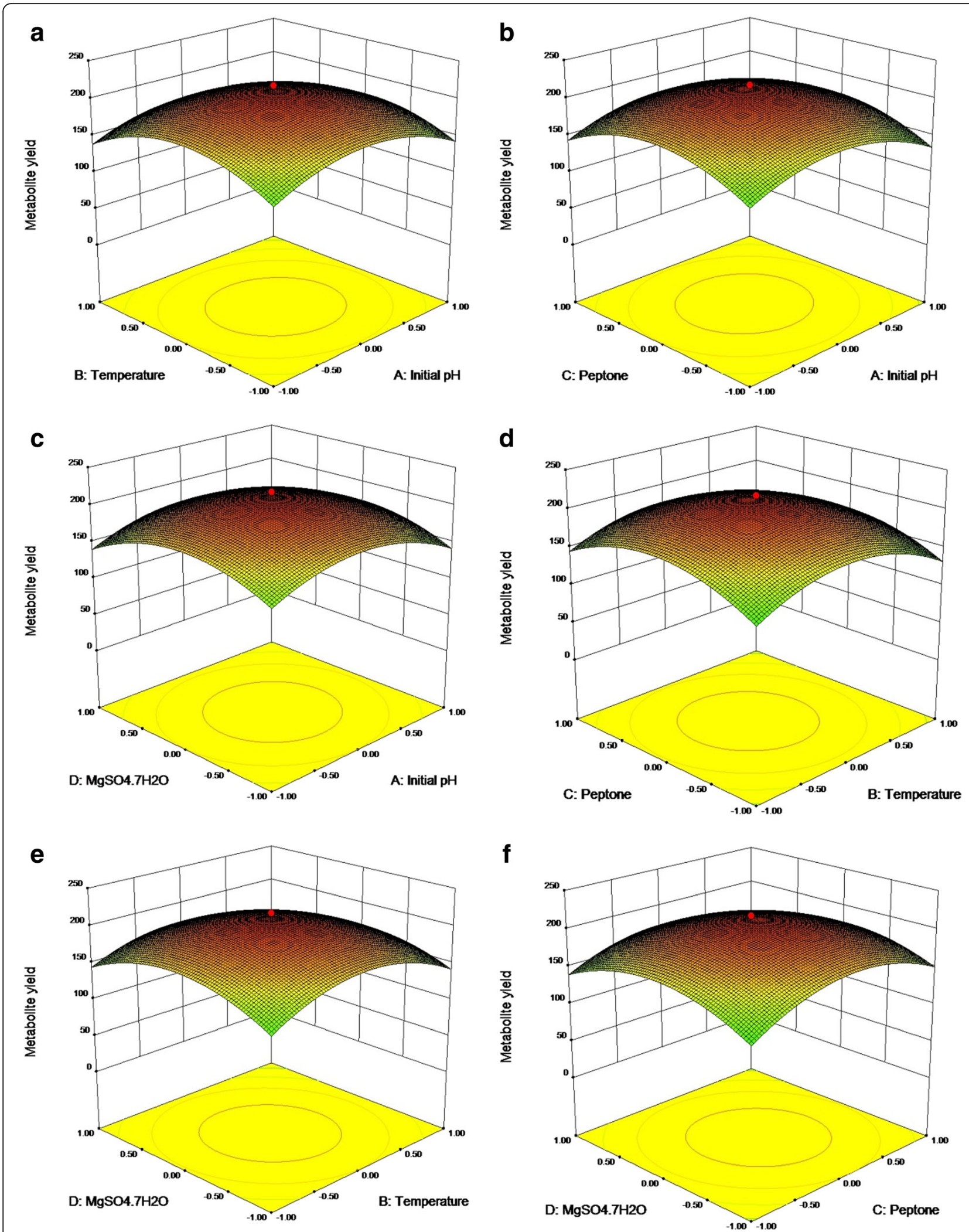

Fig. 6 Response surface curve showing the various interaction effects. a Initial pH and temperature (b) Initial pH and peptone (c) Initial pH and $\mathrm{MgSO}_{4} \cdot 7 \mathrm{H}_{2} \mathrm{O}$ (d) Temperature and peptone (e) Temperature and $\mathrm{MgSO}_{4} \cdot 7 \mathrm{H}_{2} \mathrm{O}$ (f) Peptone and $\mathrm{MgSO}_{4} \cdot 7 \mathrm{H}_{2} \mathrm{O}$ 

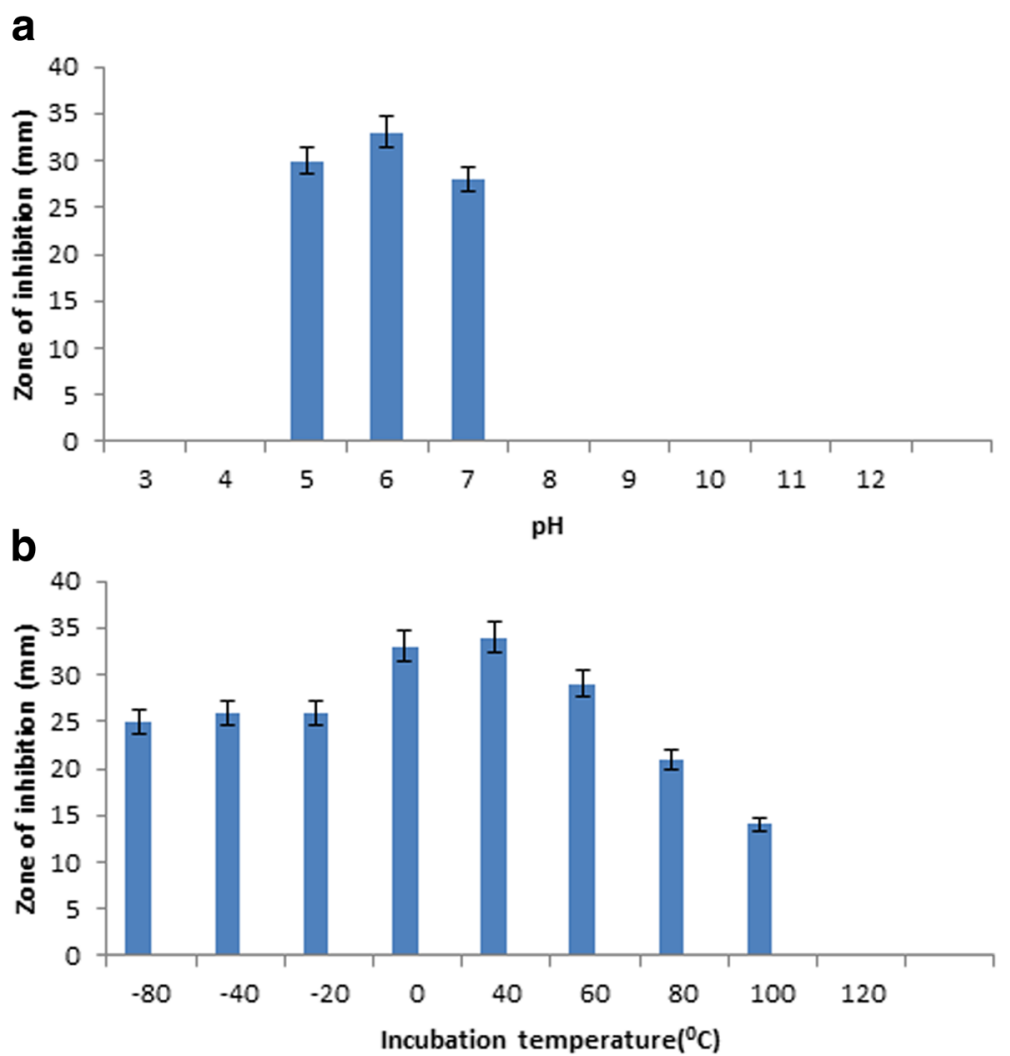

Fig. 7 Antibiotic stability in different $\mathrm{pH}$ (a) and temperatures (b)

\section{Identification of the strain}

The strain was identified by ITS region sequencing. Mycelia was ground under liquid nitrogen and DNA extraction was done from 4-day-old cultures using a HiPurATM plant genomic DNA Miniprep purification spin kit (HimediaR). Amplification of the ITS region of the fungal isolate was performed by forward primer ITS1 5-TCC GTA GGT GAA CCT GCG G-3and reverse primer ITS4 5-TCC TCC GCT TAT TGA TAT GC-3|. The PCR reaction was carried out in a $50-\mu \mathrm{L}$ reaction mixture containing $50 \mathrm{ng}$ genomic DNA, $10 \mathrm{pmol}$ of each primer, $0.5 \mathrm{mM}$ of dNTPs, $1 \times$ PCR buffer with $1.5 \mathrm{mM}$ $\mathrm{MgCl} 2$, and $3 \mathrm{U}$ Taq polymerase. The conditions consisted of an initial denaturation at $94{ }^{\circ} \mathrm{C}$ for 5 Min, followed by 35 amplification cycles at $94{ }^{\circ} \mathrm{C}$ for $1 \mathrm{Min}$, $54{ }^{\circ} \mathrm{C}$ for $1 \mathrm{Min}$, and $72{ }^{\circ} \mathrm{C}$ for $2 \mathrm{Min}$, and a final extension at $72{ }^{\circ} \mathrm{C}$ for $8 \mathrm{Min}$. The PCR product was electrophoresed on $1.2 \%$ agarose gel and desired band of $600 \mathrm{bp}$ excised. DNA from the gel slice was eluted using a GeneJETTM Gel Extraction kit (Fermentas, India) according to the manufacturer's instructions. The sequence of the PCR product was determined by employing the ABI Prism Big Dye Terminator v. 3.1 Cycle Sequencing kit. The sequence elucidation was performed on a $3730 \times$ genetic analyzer (Applied BiosystemsTM, Foster City, CA, USA). Analysis of the sequences was done using the gapped BLASTn (http://www.ncbi.nlm.nih.gov) search algorithm. The evolutionary distances among the fungal strains and their related taxa were calculated with Molecular Evolutionary Genetics Analysis (MEGA) software version 4.0. (CopyrightC Sudhir Kumar, Centre for Evolutionary Functional Genomics, 2007) using Kimura's two-parameter model, after aligning the sequences with ClustalW. The ITS region sequence of the potent strain MKH7 was submitted to the Gene Bank and assigned the accession number HM049911.

\section{Chemicals}

All media components and chemicals used were of highest purity grade available commercially from Sigma (St. Louis, USA) and Hi-media Ltd., India.

\section{Media and cultivation}

The stock culture of the filamentous fungus was maintained on potato dextrose agar slants. The slants were inoculated with mycelia and incubated at $25{ }^{\circ} \mathrm{C}$ for 7 days, and then stored at $4{ }^{\circ} \mathrm{C}$. Seed culture was grown in $250 \mathrm{ml}$ flasks containing $50 \mathrm{ml}$ of basal medium $(20 \mathrm{~g} / \mathrm{l}$ dextrose, $4 \mathrm{~g} / \mathrm{l}$ peptone, $0.5 \mathrm{~g} / \mathrm{K}_{2} \mathrm{HPO}_{4}, 0.5 \mathrm{~g} / \mathrm{KH}_{2} \mathrm{PO}_{4}, 0.5 \mathrm{~g} / \mathrm{l} \mathrm{MgSO}$. $7 \mathrm{H}_{2} \mathrm{O}$ ) at $25{ }^{\circ} \mathrm{C}$ for 4 days on a rotary shaker incubator 
(Kuhner, Switzerland) at $200 \mathrm{rpm}$. The subsequent flask culture experiments were performed in $250 \mathrm{ml}$ flasks containing $50 \mathrm{ml}$ of the media after incubating with $5 \%(\mathrm{v} / \mathrm{v})$ of the seed culture under the conditions described above.

\section{Isolation of metabolites}

Metabolite isolation and purification was done by the method described by Breinholt et al. [27]. The solvent layer was evaporated in a rotary evaporator (Buchi 114, Germany) under high vacuum. Bioassay-guided fractionation was followed to pool out the fraction having antagonistic activity against $C$. albicans. The active compound was identified following analytical tools such as IR, NMR, GCMS, and UV. A Perkin Elmer System 2000 FTIR spectrometer was used to record the IR spectra. The UV absorption spectrum was measured with an Analytik Jena UV-Vis Specord200 spectrophotometer and the operating software was Aspect plus v1.7. $1 \mathrm{H}$ NMR (300 MHz) and 13C NMR (75 MHz) spectra were obtained with a Bruker AVANCE DPX 300 NMR spectrometer in $\mathrm{CDCl} 3$ using TMS as the internal standard. Mass spectra were recorded on a Bruker Esquire 3000 system.

\section{Experimental design and statistical analysis Plackett-Burman factorial design}

Plackett-Burman designs are very efficient screening designs when only main effects are of interest. The independent variables of the culture conditions were dextrose, peptone, $\mathrm{NaCl}$, intial $\mathrm{pH}$, temperature, fermentation time, $\mathrm{MgSO}_{4} \cdot 7 \mathrm{H}_{2} \mathrm{O}$. To determine the key fermentation parameters significantly affecting metabolite production, Plackett-Burman design was employed. Based on the Plackett-Burman factorial design, each factor was tested at low $(-1)$ and high $(+1)$ levels. Plackett-Burman experimental design is based on the first-order polynomial model:

$$
\mathrm{Y}=\beta_{0}+\sum \beta_{\mathrm{i}} \mathrm{X}_{\mathrm{i}}
$$

where $Y$ is the response (productivity), $\beta_{0}$ is the model intercept, $\beta_{i}$ is the linear coefficient, and $X_{i}$ is the level of the independent variable.

\section{Central composite design (CCD) and response surface analysis}

To enhance the production of the active metabolite, the 4 most significant factors viz. initial $\mathrm{pH}$, temperature, peptone and $\mathrm{MgSO}_{4} \cdot 7 \mathrm{H}_{2} \mathrm{O}$ (screened by Plackett-Burman design) were optimized by employing $\mathrm{CCD}$ of response surface methodology. The CCD experimental results were fitted with a second-order polynomial equation and a multiple regression of the data was carried out for obtaining an empirical model related to the most significant factors. The general form of the second-order polynomial equation is

$$
\mathrm{Y}=\beta_{0}+\sum \beta_{\mathrm{i}} \mathrm{X}_{\mathrm{i}}+\sum \beta_{\mathrm{ii}} \mathrm{X}_{\mathrm{i}}^{2}+\sum \beta_{\mathrm{ij}} \mathrm{X}_{\mathrm{i}} \mathrm{X}_{\mathrm{j}}
$$

where $Y$ is the predicted response, $X_{i}$ and $X_{j}$ are independent factors, $\beta_{0}$ is the intercept, $\beta_{i}$ is the linear coefficient, $\beta_{\mathrm{ii}}$ is the squared coefficient, and $\beta_{\mathrm{ij}}$ is the interaction coefficient. The relation between the coded and the actual can be determined as follows:

$$
X i=\frac{U i-U i o}{\Delta U i}
$$

where $X i$ is the coded value of the $i$ th variable, $U i$ is the actual value of the $i$ th variable, Ui0 is the actual value of the $i$ th variable at the center point, and $\Delta U i$ is the step change of variable.

The data obtained from RSM were subjected to the analysis of variance (ANOVA). The quality of fit of the second-order model equation was expressed by the regression coefficient $R^{2}$ and its statistical significance was determined by an $F$-test. The significance of each regression coefficient was determined using Student's $t$-test. Three-dimensional plots and their respective contour plots were obtained based on the effects of the levels of two parameters and their interactions on the production of the bioactive compound by keeping the other two parameters at their optimal concentrations. The computer software used for the experimental designs and statistical analysis of the experimental data was Design-Expert version8.0 (Stat-Ease Inc., Minneapolis, U. S. A.).

\section{Validation of the model}

In order to confirm the optimized culture conditions, all experiments were performed in triplicates and results represented the mean values of three independent experiments.

\section{Characterization of the purified metabolite}

The bioactive metabolite was characterized with respect to thermal and $\mathrm{pH}$ stability. Susceptibility of the compound to different temperatures was ascertained according to the method described by Lee et al. [52]. $\mathrm{pH}$ stability was estimated after $4 \mathrm{~h}$ of storage at $4{ }^{\circ} \mathrm{C}$ in the following buffers: $50 \mathrm{mM}$ sodium acetate buffer (pH3-5), $50 \mathrm{mM}$ phosphate buffer (pH6-7), Tris- $\mathrm{HCl}$ buffer (pH8-9). The samples were then neutralized followed by agar diffusion assay. $\mathrm{pH}$ measurement was done with a Eutech $\mathrm{pH} 700$ $\mathrm{pH}$ meter, calibration was done at the appropriate temperature with standard solutions ( $\mathrm{pH} 7.4$ and 10) provided with the instrument. Determination of antibiotic activity was done by measurement of the zones of inhibition; measurements were taken from the edge of the antibiotic disk to the margin of the zone [24]. 


\section{Abbreviations}

CCD, central composite design; PBD, Plackett-Burman design; RSM, response surface methodology

\section{Acknowledgements}

The authors are also thankful to the Director, CSIR-NEIST, for providing necessary facilities to carry out the work.

\section{Funding}

The authors are grateful to the funding agency, Council of Scientific \& Industrial Research (CSIR), for the grants.

\section{Availability of data and materials}

The datasets supporting the conclusions of this article are included within the article.

\section{Authors' contributions}

ST and TCB conceptualized and designed the experiments. ST, MT, MB and AY performed the experiments. ST and RNSY analyzed the data. ST prepared the manuscript. All authors read and approved the final manuscript.

\section{Competing interests}

The authors declare that they have no competing interests.

\section{Consent to publish}

Not applicable.

\section{Ethics and consent to participate}

Not applicable.

\section{Author details}

'Biotechnology Division, CSIR-North-East Institute of Science \& Technology, Jorhat 785006, Assam, India. ${ }^{2}$ Department of Life Sciences, Dibrugarh University, Dibrugarh 786004, Assam, India.

Received: 6 October 2015 Accepted: 19 May 2016

Published online: 09 December 2016

\section{References}

1. Joshua DN. Current status and future of antifungal therapy for systemic mycoses. Recent Pat Antiinfect Drug Discov. 2006;1:75-84.

2. Afraseyabi S, Afkhamzadeh A, Sabori H, Verdi F, Khaksar N, Mosavei B, Kalantar E. Oral candidiasis amongst cancer patients at Qods hospitals in Sanandaj. Afr J Cln Exper Microbiol. 2011;12:129-32.

3. Nguyen MH, Peacock JE, Jr Morris AJ, Tanner DC, Nguyen ML, Snydman DR, Wagener MM, Rinaldi MG, Yu VL. The changing face of candidemia: Emergence of non-Candida albicans species and antifungal resistance. Am J Med. 1996:100:617-23.

4. Newman DJ, Cragg GM. Natural products as sources of new drugs over the 30 years from 1981 to 2010. J Nat Prod. 2012;75:311-35.

5. McIntyre M, Muller C, Dynesen J, Nielsen J. Metabolic Engineering of the Morphology of Aspergillus. Adv Biochem Eng/Biotech. 2001;73:104-28.

6. Nicoletti R, Lopez-Gresa MP, Manzo E, Carella A, Ciavatta ML. Production and fungitoxic activity of Sch 642305, a secondary metabolite of Penicillium canescens. Mycopathologia. 2007;163:295-301.

7. Rancic A, Sokovic M, Karioti A, Vukojevic J, Skaltsa H. Isolation and structural elucidation of two secondary metabolites from the filamentous fungus Penicillium ochrochloron with antimicrobial activity. Environ Toxicol Pharmacol. 2006:22:80-4.

8. Lucas EMF, Machado Y, Ferreira AA, Dolabella LMP, Takahashi JA. Improved Production of Pharmacologically-active Sclerotiorin by Penicillium sclerotiorum. Trop J Pharma Res. 2010;9:365-71.

9. Mangamuri UK, Poda S, Kamma S, Muvva V. Optimization of Culturing Conditions for Improved Production of Bioactive Metabolites by Pseudonocardia sp. VUK-10. Mycobiology. 2011;39(3):174-81.

10. Li $Y$, Jiang $H, X u Y$, Zhang $X$. Optimization of nutrient components for enhanced phenazine-1-carboxylic acid production by gacA-inactivated Pseudomonas sp. M18G using response surface method. Appl Microbiol Biotechnol. 2008;77:1207-17.

11. Reddy PRM, Mrudula S, Ramesh B, Reddy G, Seenayya G. Production of thermostable pullulanase by Clostridium thermosulfurogenes SV2 in solid- state fermentation: optimization of enzyme leaching conditions using response surface methodology. Bioprocess Eng. 2000:23:107-12.

12. Poorna $V$, Neelesh RS. Statistical designs for optimisation of process parameters for alpha amylase production by $A$. flavus under solid state fermentation of Amaranthus paniculatas grains as a new source of starch. J Basic Microbiol. 2001;41:57-64.

13. Qasim KB, Vikram S, Rani G. Statistical media optimization and alkaline protease production from Bacillus mojavensis in a bioreactor. Process Biochem. 2003:39:203-9.

14. Balusu R, Paduru RR, Kuravi SK, Seenayya G, Reddy G. Optimization of critical medium components using response surface methodology for ethanol production from cellulosic biomass by Clostridium thermocellum SS19. Process Biochem. 2005:40:3025-30.

15. Li C, Bai JH, Cai ZL, Ouyang F. Optimization of a cultural medium for bacteriocin production by Lactococcus lactis using response surface methodology. J Biotechnol. 2002;93:27-34.

16. Francis F, Sabu A, Nampoothiri KM, Ramachandran S, Ghosh S, Szakacs G, Pandey A. Use of response surface methodology for optimizing process parameters for the production of a-amylase by Aspergillus oryzae. Biochem Eng J. 2003;15:107-15

17. Sayyad SA, Panda BP, Javed S, Ali M. Optimization of nutrient parameters for lovastatin production by Monascus purpureus MTCC 369 under submerged fermentation using response surface methodology. Appl Microbiol Biotechnol. 2007;73:1054-8

18. Liu GQ, Wang XL. Optimization of critical medium components using response surface methodology for biomass and extracellular polysaccharide production by Agaricusblazei. Appl Microbiol Biotechnol. 2007;74:78-83.

19. Deepak V, Kalishwaralal K, Ramkumarpandian S, Babu SV, Senthilkumar SR, Sangiliyandi G. Optimization of media composition for Nattokinase production by Bacillus subtilis using response surface methodology. Bioresour Technol. 2008:99:8170-4.

20. Li XY, Liu ZQ, Chi ZM. Production of phytase by a marine yeast Kodamaed ohmeriBG3 in an oats medium: Optimization by response surface methodology. Bioresour Technol. 2008;99:6386-90.

21. Chang YN, Huang JC, Lee CC, Shih IL, Tzeng YM. Use of response surface methodology to optimize culture medium for production of lovastatin by Monascus ruber. Enzyme Microb Technol. 2002;30:889-94.

22. Valliappan K, Chandramohan A, Kannan S, Lakshmanan K. Statistical optimization and anticancer activity of a red pigment isolated from Streptomyces sp. PM4. Asian Pac J Trop Biomed. 2013;3(8):650-6.

23. Sharma KK, Shrivastava B, Sastry VRB, Sehgal N, Kuhad RC. Middle-redox potential laccase from Ganoderma sp.: its application in improvement of feed for monogastric animals. Sci Rep. 2013;3:1299.

24. Wang $Y$, Fang $X$, An F, Wang G, Zhang $X$. Improvement of antibiotic activity of Xenorhabdus bovienii by medium optimization using response surface methodology. Microb Cell Fact. 2011;10:98.

25. Cole R, Kirksey JW, Moore JH, Blankenship BR, Diener UL, Davis ND. Tremorgenic Toxin from Penicillium Verruculosum. Appl Microbiol. 1972;24:248-56.

26. Sakamoto S, Kojima F, Igarashi M, Sawa R, Umekita M, Kubota Y, Nakae K, Yamaguchi S, Adachi H, Nishimura Y, Akamatsu Y. Decalpenic acid, a novel small molecule from Penicillium verruculosum CR37010, induces early osteoblastic markers in pluripotent mesenchymal cells. J Antibiot 2010;63:703-8.

27. Breinholt J, Jensen GW, Nielsen RI. Antifungal macrocyclic polylactones from Penicillium verruculosum. J Antibiot. 1993;46:1101-8.

28. Ito M, Maruhashi M, Sakai N, Mizoue K, Hanada K. NG-01 1 and NG-012, Novel Potentiators of Nerve Growth Factor I. Taxonomy, Isolation, and Physico-Chemical and Biological Properties. J Antibiot. 1992:45:1559-65.

29. Curtis PJ, Hemming HG, Unwin $\mathrm{CH}$. Albidin, an antibiotic red pigment from Penicillium albidum. Trans Brit mycol Soc. 1950;23:332-9.

30. Brian PW, Curtis PJ, Hemming HG, Norris GLF. Wortmannin, an antibiotic produced by Penicillium Wortmanni. Trans Brit mycol Soc. 1957:40(3):369-74

31. Betina V. Physiological regulation of secondary metabolism. In: Betina V, editor. Bioactive secondary metabolite of microorganisms: Process in industrial Microbiology. Amsterdam \& New York: Elsevier Science; 1994. p. 66-80.

32. Wang ZW, Liu XL. Medium optimization for antifungal active substances production from a newly isolated Paenibacillus sp. using response surface methodology. Bioresour Technol. 2008;99:8245-51. 
33. Prapulla SG, Jacob Z, Chand N, Rajalakshima D, Karanth NG. Maximization of lipid production by Rhodotorula gracilis CFR-1 using response surface methodology. Biotechnol Bioeng. 1992;40:965-9.

34. Mu WM, Chen C, Li XF, Zhang T, Jiang B. Optimization of culture medium for the production of phenyllactic acid by Lactobacillus sp. SK007. Bioresour Technol. 2009;100:1366-70.

35. Pimenta EF, Vita-Marques AM, Tininis A, Seleghim MHR, Sette LD, Veloso K, Ferreira AG, Williams DE, Patrick BO, Dalisay DS, Andersen RJ, Berlinck RGS. Use of Experimental Design for the Optimization of the Production of New Secondary Metabolites by Two Penicillium Species. J Nat Prod. 2010;73:1821-32.

36. Venkata Dasu V, Panda T, Chidambaram M. Determination of significant parameters for improved griseofulvin production in a batch bioreactor by Taguchi's method. Process Biochem. 2003;38:877-80.

37. Ahmad A, Panda BP, Mujeeb M. Screening of nutrient parameters for mevastatin production by Penicillium citrinum MTCC 1256 under submerged fermentation using the Plackett Burman design. J Pharm Bioallied Sci. 2010;2(1):44-6.

38. Demain AL. Microbial secondary metabolism: a new theoretical frontier for academia, a new opportunity for industry. In: Chadwick DJ, Whelan D, editors. Secondary metabolites: their function and evolution. Chichester: John Wiley \& Sons; 1992.

39. Zhou J, Liu L, Shi Z, Du G, Chen J. ATP in current biotechnology: regulation, applications and perspectives. Biotechnol Adv. 2009;27(1):94-101.

40. Méndez A, Pérez C, Montañéz JC, Martínez G, Aguilar CN. Red pigment production by Penicillium purpurogenum $\mathrm{GH} 2$ is influenced by $\mathrm{pH}$ and temperature. Biomed Biotechnol. 2011;12(12):961-8.

41. Brian PW. Production of gliotoxin by Penicillium terlikowskii ZAL. Trans Bri Mycolo Society. 1946;29:211-8.

42. Kansoh AL, Khattab OH, Abd-Elrazek ZM, Motawea HM. Broad spectrum antimicrobial agent from a local isolate of marine fungus strain. J Appl Sci Res. 2010;6(6):580-8.

43. Merlin JN, Christhudas IVSS, Kumar PP, Agastian P. Optimization of growth and bioactive metabolite production: Fusarium Solani. Asian J Pharm Clin Res. 2013:6:98-103.

44. Wu MT, Ayres IJC, Koehler PE. Production of Citrinin by Penicillium viridicatum on Country-Cured Ham. Appl Microbiol. 1974:27:427-8.

45. Raab WP. Natamycin (Pimaricin): Its properties and possibilities in Medicine. Stuttgart: Georg Thieme Publishers; 1972.

46. Stark J. Permitted preservatives- natamycin. In: Robinson RK, Batt CA, Patel PD, editors. Encyclopedia of Food Microbiology. San Diego: Academic; 2000. p. 1776-81.

47. Hamilton-Miller JMT. The effect of $\mathrm{pH}$ and of temperature on the stability and bioactivity of nystatin and amphotericin B. J Pharm Pharmacol. 1973;25:401-7.

48. Choudhuri SD, Ayers S, Soine WH, Reynolds KA. A pH-Stability Study of Phoslactomycin B and Analysis of the Acid and Base Degradation Products. J Antibiot. 2005;58:573-82.

49. Brik H. New high-molecular decomposition products of natamycin (pimaricin) with intact lactone-ring. J Antibiot. 1976;29:632-7.

50. Gramer A. Antibiotic sensitivity and assay tests. In: Collins CH, Lyne PM, editors. Microbiological methods. Butterworth and Co., London; 1976. p. 235.

51. Forbes BA, Sahm DF, Weissfeld AS, Trevino EA. Methods for testing antimicrobial effectiveness. In: Baron EJ, Peterson LR, Finegold SM, editors. Bailey scotts diagnostic microbiology. St Louis: Mosby Co; 1990. p. 171-94.

52. Lee YK, Senthilkumar M, Kim JH, Swarnalakshmi K, Annapurna K. Purification and partial characterization of antifungal metabolite from Paenibacillus lentimorbus WJ5. World J Microbiol Biotechnol. 2008;24:3057-62.

\section{Submit your next manuscript to BioMed Central and we will help you at every step:}

- We accept pre-submission inquiries

- Our selector tool helps you to find the most relevant journal

- We provide round the clock customer support

- Convenient online submission

- Thorough peer review

- Inclusion in PubMed and all major indexing services

- Maximum visibility for your research

Submit your manuscript at www.biomedcentral.com/submit

) Biomed Central 